Lats M.P.

\title{
Nuclear weapons: implications for the Middle East
}

Siberian Federal university

(Russia, Krasnoyarsk)

doi: $10.18411 / \mathrm{lj}-05-2021-328$

\section{Аннотация}

В начале второго тысячелетия мировые державы могли с уверенностью утверждать, что режим ядерного нераспространения смог выдержать испытание временем. Учитывая тот факт, что еще в 1960-х годах эксперты с недоверием относились к нераспространению, предсказывая резкий рост «ядерного клуба» к концу $\mathrm{XX}$ века, только 4 державы «переступили ядерный порог», что говорит об эффективности Договора о нераспространении ядерного оружия (ДНЯО). Кроме того, проблема нераспространения продемонстрировала тенденцию к регионализации. На Ближнем Востоке в центре внимания находится ядерная безопасность и перспективы появления новых ядерных государств.

Ключевые слова: Ближний Восток, ядерное оружие (ЯО), нераспространение, Договор о нераспространении ядерного оружия (ДНЯО), Иран, Израиль, США, Турция.

\section{Abstract}

At the beginning of the second millennium world powers could confidently claim that the nuclear non-proliferation regime (NPR) was quite successful and withstood the test of time. Given the fact that back in the 1960s experts were mistrustful of the non-proliferation, predicting a biting increase in the number of countries-owners of nuclear weapon (NW) by the end of the 20th century, the regime survived, allowing only four powers to enter the expanded Nuclear Club. Besides, the issue of proliferation showed a trend towards regionalization. Today, however, it isn't easy to be confident about the nuclear margin of safety, especially in the Middle East where the process of counteracting the states' nuclearization is in the limelight.

Keywords: Middle East (ME), nuclear weapons (NW), non-proliferation, nonproliferation treaty (NPT), Iran, Israel, USA, Turkey.

The Middle East is one of the most dangerous regions in the world where nuclear proliferation threats are concentrated and the geopolitical interests of the world powers collide. This is manifested in the fact that non-proliferation regime has already been violated or there are factors which are contributing to its rapid disruption [1]. The Non-Proliferation Treaty (NPT), the cornerstone of the entire NPR, is a multilateral treaty designed to limit the spread of NW including non-proliferation, disarmament and peaceful use of nuclear energy. These elements constitute a 'grand bargain', according to which states without NW will not acquire them, states with NW will pursue disarmament, all states can access nuclear technology for peaceful purposes under safeguards [2].

In this article, we will focus on the danger of nuclear proliferation in the Middle East trying to find out whether the risks are significant or not.

Maintenance of the non-proliferation of nuclear weapons in the Middle East is currently an urgent problem for the entire world community. Latest months have brought a number of events to the news agenda regarding Middle Eastern atom. Such as the recent news reported by The New York Times with the following heading: 'Israel blew up Iranian centrifuges in Natanz'. A fire at Iran's main nuclear fuel enrichment site caused significant damage, setting back the country's nuclear programme. Earlier, Iran`s nuclear infrastructure was cyberattacked. In the past, Israel used to deliver targeted airstrikes in order to destroy nuclear facilities in the Middle East. The Osirak nuclear reactor in Iraq was destroyed by the 
Israeli Air Force in 1981. Also, in 2007 the Israeli military during an air raid destroyed an alleged nuclear reactor in the Syrian province of Deir ez-Zor [3].

Actually, Tehran is under serious pressure from the United States and Israel which consider Iran to be their main geopolitical adversary. If Iran acquires nuclear weapons, the game in the region will change and the threat of nuclear proliferation in the Middle East will increase [4, p. 97-98].

The Middle East region has a 'default' nuclear power that is not officially recognized and remains outside the Treaty on the non-proliferation of Nuclear Weapons - the State of Israel. The NPT does not include Israel which refused to join the treaty as a non-nuclear state. Israel also does not support a Treaty Banning the Production of Fissile Material for Military Purposes, what gives the opportunity to develop weapons-grade nuclear materials without any obstacles [5]. According to various sources, the number of Israeli warheads varies between 80 and 200. Israel's undeclared nuclear arsenal in the future will remain the most important component of the military-strategic balance in the region, a significant component in Tel Aviv's relations with the Arab states.

Ernest J. Moniz, CEO of the Nuclear Threat Initiative, in his article sets the task of drawing the attention of the international community to the changed nature of the nuclear threat from Israeli and Iranian nuclear programmes. Also it's impossible to ignore nuclear energy ambitions of Saudi Arabia, Egypt, Turkey and others. This is one example of heightened regional proliferation concerns [6]. In this regard, there are approaches to mitigate proliferation anxiety by providing opportunities in four different non-proliferation areas: detection, prevention, rollback and subnational risks.

The position of Israel supported by the US leads to the fact that other countries in the region, such as Iran, don't want to give up their nuclear programmes. Israel is a state with 'undeclared' but highly balanced means of delivery which can be immediately armed with NW, turning into (trans)regional nuclear deterrent forces. Such types of weapons cannot be ignored by any potential adversary. The only thing that was announced by the country's leadership is that Israel won't use NW first in the ME and should remain the only nuclear power in the region. Therefore, it seems that Israel regards nuclear weapons as a guarantee of 'survival' in the Middle East, surrounded by 'hostile Muslim states' [5].

One of the main features of the modern Israeli nuclear programme is a special relationship between Israel and the US. Israel, being a member of the International Atomic Energy Agency (IAEA), doesn't participate in international agreements on the control of nuclear exports and ignores the idea of creating a nuclear-free zone in the Middle East $[4, \mathrm{p}$. 100].

At the same time, Israel's abandonment of nuclear weapons is much more difficult to achieve. Among such conditions is the resolution of the Iranian nuclear problem. Along with measures of transparency, only reliable guarantees of Israel's security could raise the issue of Tel Aviv's refusal to an upper-echelon [5]. There is another option of disarming Israel on the model of South Africa, but then a state will have to admit the presence of NW. Together with this, one of the most acute regional conflicts in international relations after the Second World War, the Arab-Israeli conflict, remains unresolved. The Arab / Palestinian-Israeli settlement is like a 'Mobius loop': wherever you start moving along it, you will move forever. It seems that this model best describes what is happening today in the Middle East. An endless process with ups and downs, but without progress. The nuclear 'Mobius loop' lead to multiple duplication and complication in the already complex geopolitical space [7].

It is also worth mentioning that nuclear arsenals are stationed at NATO military bases in Turkey. A number of Middle Eastern countries have either had military nuclear programmes in the past, or have the technical and technological potential to develop nuclear weapons.

Iran's development of nuclear technologies has already resulted in the Middle East 'atomic domino effect' (a peculiar feature of global arms control): when the countries of the 
Middle East were watching the development of the Israeli, Indian and Pakistani nuclear programmes. Nuclear status has become a national priority for UAE, Turkey, Saudi Arabia, Egypt and Algeria. Jordan, Syria, Iraq have expressed or are expressing their intention to develop nuclear energy [7].

An analysis of Iran's nuclear programme may give the impression that it is seeking for NW in violation of its obligations. The NPT and membership in the IAEA do not prohibit their own developments in the field of peaceful nuclear energy. The country has several groups in government departments and political circuits who are struggling over the question of the need to create NW. National security considerations, regional prestige (compared to India, Pakistan, Israel), and domestic political considerations tend to favor the development of a military nuclear program. At the same time, interest in cooperation with the West in the economic, military and political fields as well as fear of preventive military actions work against such a programme [5].

Today, the existence of various methods for resolving the Iranian problem demonstrate their ineffectiveness. Any military operation will most likely have the opposite effect crossing the 'nuclear threshold' [8]. Apparently, the internal political consensus in Iran boils down to the need to preserve the potential of a possible future 'nuclear choice'.

Saudi Arabia (SA), one of the richest states in the ME, which signed the NPT, has no right to acquire strategic NW or tactical ones. There are concerns that King Salman just can declare that this purchase was made on his behalf, and the Agreement does not apply to such a transaction. Everyone knows that the state of SA is the property of the king. So the privatization of NW - a scenario so far unimaginable - is highly likely. The emergence of a new nuclear player in the Middle East outside the sphere of control will upset the already fragile nuclear balance in the region [7].

Turkey is also developing a series of ballistic missiles capable of carrying a nuclear warhead. It is a controversial question whether United States should remove NW from Turkey or not. Thus, Turkey is of great concern not only because of its territorial location, but also because of the instability of the political regime [9].

As for other countries in the Middle East, their interest in nuclear weapons may increase in case of nuclear destabilization of the region. First of all, the reason may be a step by Iran towards the achievement of nuclear status or military intimidation by the US or any other Islamic country under the veil of fighting against international terrorism or weapons of mass destruction (WMD). According to the Prince of Saudi Arabia, the Kingdom does not want to acquire nuclear weapons. However, if Iran succeeds in obtaining it, Saudi Arabia will direct all efforts to create its own nuclear arsenal. Thus, it is likely that its neighbors will also have them. If Egypt launches a NW programme, there are fears that its key rival, Algeria, will also join the arms race. For decades, Algeria operated a large research reactor because a state has tons of spent reactor fuel, enough for a nuclear arsenal [7]. Egypt has 2 research reactors with IAEA guarantee. Although the state doesn't have the ability to produce weapons-grade nuclear materials, in 1998 Cairo stated about the creation of NW in case of a military-political need for it. Syria is cooperating with Russia in the peaceful use of nuclear energy, because the country lacks scientific and technical prerequisites for the creation of NW [5].

Considering that the Saudi Arabia is one of the main sources of funding for the Pakistani nuclear programme, and the creator of the Islamic nuclear bomb, A. Khan, had contacts with the Saudis, the potential source of threat might come from Saudis. However, the facts about any serious nuclear programme in Riyadh have not yet been discovered. After Libya's refusal to possess or create NW and the transfer of the available materials and equipment to the US, Tripoli can be excluded from the list of potential owners of NW in the long term [5].

Since it will be extremely difficult for other states in the ME to gain access to nuclear weapons alone, it is possible for these countries to unite their efforts in the nuclear field, cooperate in order to create key links in the nuclear fuel cycle. It cannot be ruled out that 
Saudi Arabia or UAE would contribute to the development of the nuclear capabilities, then make it possible to buy ready-made nuclear warheads, a sufficient amount of weapons-grade nuclear materials or hunt nuclear specialists [9].

Saudi Arabia and Turkey should become key signatories as some of Iran's fiercest opponents due to the fact that both states have ambitious nuclear plans. In this regard, such condition and the successful transfer of the provisions of the JCPOA to the global level could contribute to the establishment of new NPR. That regime may not eliminate all the threats associated with Iran, but it would prevent Tehran from creating nuclear weapons. It also may become the basis for the transformation of the Middle East into a zone free of NW. This is what the international community should value as its highest priority [10]. The idea of a Middle East Nuclear-Weapon-Free Zone (NWFZ) has existed for 35 years. In principle, all states in the region have expressed support for a multilateral regional non-proliferation framework, but in practice, no progress has been made. Such framework was implied to encompass energy, security, and arms control initiatives which should reduce the nuclear threat and risks [11].

And we would also like to draw your attention to one more important aspect of the problem. There are the largest footholds of international terrorism. Regarding the Middle East, it is worth taking non-state actors' threats into account. Although most experts still consider the threat of nuclear terrorism to be rather hypothetical, it is necessary to be prepared to respond to it in such unstable regions as the Middle East in advance [5].

The beginning of the XXI century revealed a new threat of nuclear proliferation - the improvement of methods of terrorist activity. The 9/11 terrorist attack demonstrated that terrorist organisations are capable of large-scale actions requiring the use of advanced technologies. Today states are the only entities that have sufficient financial resources and capabilities to create a nuclear charge, but improving uranium enrichment technologies can put an end to the states' monopoly on the creation of NW [1].

There is also an alarmist scenario which envisages that terrorist groups such as $\mathrm{Al}$ Qaeda (AQ) exploit 'proliferation rings', such as the AQ Khan network to acquire nuclear weapons. However, this 'catastrophic' scenario does not mean that terrorism would indeed represent a major disaster. Much more likely would be that terrorists might concentrate on radioactive materials (e.g. non-enriched or even depleted uranium) and use this for radiological weapons, better known as 'dirty bombs'. Fortunately, however, the destruction following such an attack would be quite modest and the safeguards against it rather obvious.

Today, few people believe in a nuclear-free future for the Middle East. Stopping the proliferation of NW in the ME is unlikely to succeed, so it's necessary to make the nuclear potential play a stabilizing role in order to establish a balance of power. One of the reasons lies in the uniqueness of the Middle East as a region in which various competing cultures, ethnic groups and religions coexist [9]. The 'Arab Spring' froze the negotiation process on nuclear security in the ME for a long time. While the active participation and consent of all regional states would be an ideal basis for starting the WMD-free zone process in the Middle East, the first steps towards implementation of the zone could be taken 'without Israel on a board' [12].

The reluctance of the international community to take steps towards nuclear nonproliferation in the Middle East and the creation of additional guarantees is a serious threat to the Treaty on the non-proliferation of Nuclear Weapons. In this case, the problem of distribution of control over nuclear arsenals will inevitably arise. Establishment of the Nuclear-Weapon-Free Zone in the Middle East isn't an easy task, but relative success can only be achieved with the goodwill of all participants [13].

The proliferation of nuclear weapons remains one of the biggest threats to the Middle East security architecture. The realities of the $21^{\text {st }}$ century force the world to face new opportunities for obtaining nuclear weapons, and the Middle East is not an exception. As the new US special envoy for arms control Marshall Billingsley stated, "a new era of arms control 
has begun" [14]. But until now it looks like the dark ages of it. And so far, the question of whether it is possible to preserve the fragile balance of power in the region remains open.

In the light of the above-mentioned facts, it is clear that the implications for the nuclear non-proliferation regime in the Middle East do not seem too rosy. However, the risks of total demise of NPR in the ME in the next 5-10 years are insignificant mostly because of warrantors who preserve the status-quo and the existing collapsing global arms control. And it's too early to talk about a serious threat of an increase in nuclear states in the Middle East. The political will of the leading world powers ('Nuclear Club') and their willingness for multilateral cooperation in the ME nuclear issue are gaining. Otherwise, another spinning in the Middle East 'Mobius loop' could once again explode the situation in the region and finally bury hopes for a lasting peace.

\section{$* * *$}

1. Кортунов П. Режим распространения в XXI веке: новые вызовы и угрозы [Электронный ресурс] / РСМД. - Режим доступа: https://clck.ru/Porob.

2. Treaty on the Non-Proliferation of Nuclear Weapons [Electronic resource]. - Access mode: https://clck.ru/PornC.

3. Fassihi F., Bergman R. Iran Admits Serious Damage to Natanz Nuclear Site, Setting Back Program [Electronic resource] / NY times. - Access mode: https://clck.ru/Pork2.

4. Карасова Т.А. Ядерная программа Израиля // Контуры глобальных трансформаций: политика, экономика, право, 2018. №6. С. 97-101.

5. Угрозы режиму нераспространения ядерного оружия на Ближнем и Среднем Востоке [Электронный ресурс] / под ред. А. Арбатова и В. Наумкина. М., 2005. - Режим доступа: https://clck.ru/Porp8.

6. Moniz E. J. Nuclear Non-Proliferation: Steps for the 21st Century [Electronic resource] / Hoover Institution. 2019. - Access mode: https://clck.ru/PorjT.

7. Ядерный мир: новые вызовы режиму ядерного нераспространения [Электронный ресурс] / [под. ред. Е. Б. Михайленко], М-во образования и науки Рос. Федерации, Урал. федер. ун-т. Екатеринбург, 2017. - 432 c. - Режим доступа: https://clck.ru/PorpN.

8. Синовец П.А. Ядерное распространение на Ближнем Востоке: основные тенденции, пути предупреждения и средства борьбы [Электронный ресурс] / Институт Ближнего Востока, 2009 г. Режим доступа: https://clck.ru/Poroq.

9. Кортунов П. Атомная эпоха Ближнего Востока [Электронный ресурс] / РСМД. - Режим доступа: https://clck.ru/PoroH.

10. P. Kortunov. New Horizons of the Iran Nuclear Deal [Electronic resource] / RIAC. - Access mode: https://clck.ru/PormH.

11. Lindamood H. ME Nuclear Weapon Free Zone [Electronic resource] / Daisy Alliance. NPT Review Conference. - Access mode: https://clck.ru/Porkk.

12. The lack of disarmament in the ME: a thorn in the side of the NPT [Electronic resource] / SIPRI Insights on Peace and Security, 2019. - Access mode: https://clck.ru/Pormq.

13. Squassoni Ms.Sh. The ME and the nuclear non-proliferation regime [Electronic resource] / The Russian center for policy studies, 2011. - Access mode: https://clck.ru/Porkv.

14. Ермаков А. Новая эпоха контроля над вооружениями [Электронный ресурс] / РСМД. - Режим доступа: https://clck.ru/Porni. 